Rupkatha Journal on Interdisciplinary Studies in Humanities (ISSN 0975-2935), Vol. 10, No. 1, 2018 Special Issue on "Interrogating Cultural Translation: Literature and Fine Arts in Translation and Adaptation" In collaboration with the Department of English, Amrita Vishwa Vidyapeetham Guest-edited by Dr. Hari M G, Amrita Vishwa Vidyapeetham, Coimbatore, India DOI: https://dx.doi.org/10.21659/rupkatha.v10n1.14 Full Text: http://rupkatha.com/V10/n1/v10n114.pdf

\title{
Rendering Imagery in the Semantic Structure of Stable Terminological Word Combinations
}

\author{
R. E. Shkilev', E. V. Samsonova², I. D. Kazanchuk ${ }^{3}$, M. M. Isupova ${ }^{4}$ \\ ${ }^{1,2}$ Kazan Federal University, Russia. Email: schkilef@gmail.com \\ ${ }^{3}$ Professor, Kharkiv National University of Internal Affairs, Ukraine, \\ ${ }^{4}$ Kutafin Moscow State Law University (MSAL), Russia. \\ Corresponding email: Email: schkilef@gmail.com
}

Received December 23, 2017; Revised January 30, 2018; Accepted February 4, 2018; Published February o8, 2018.

\begin{abstract}
The article focuses on the peculiarities of rendering the meaning of compound terms in the translation process with the help of word combinations without shift of meaning in the semantic structure. The research is based on the examples from English and Russian legal terminology. Taking into account the fact that legal terms form a part of literary language the classification is based on principles accepted and used in Phraseology. The examples analyzed in this paper reveal the difference between English and Russian compound terms in the lexical and grammatical structure. The author arrives at a conclusion that the semantic shift in legal terminology has an anthropocentric orientation. The dependence of the nature of the semantic shift on certain features of national cultures is shown. The results of the investigation provide for the material for the study of the features of the corresponding segment of linguistic worldview.
\end{abstract}

Keywords: compound term, stable terminological word combination, imagery, semantic shift, equivalence, legal terminology.

\section{Introduction}

Terminology as a branch of Linguistics has a rich history and many terminological systems have been already described in detail. However, the authors of this paper believe that the comparative study of terminology of languages with different structure preserves its actuality. The scholars speak about the importance of the study of motivation of terms, thus referring to "motivation terminology" as a special field of linguistic research. In Russian linguistics the problems of motivation of terms are studied by E. Steingart (Steingart 2006).

The other important area for investigation in terminology is Cognitive Terminology. Compound terms with an imaginative rethinking in the semantic structure resemble phraseological units in many ways. This resemblance enables the scholars to use for the description of compound terms the principles accepted in research in Phraseology. These

(C) AesthetixMS 2018. This Open Access article is published under a Creative Commons Attribution Non-Commercial 4.0 International License (http://creativecommons.org/licenses/by-nc/4.0/), which permits non-commercial re-use, distribution, and reproduction in any medium, provided the original work is properly cited. For citation use the DOI. For commercial re-use, please contact editor@rupkatha.com. 
principles are outlined in the introduction to the Russian-English Phraseological Dictionary by Elena Arsentyeva (Arsentyeva 1999, 8).

We applied to the classification of stable terminological word combinations into full and partial equivalents, analogues (i.e. having a different imagery in the semantic structure) and word combinations having no equivalents in the other language in our previous works (Shkilev 2010). This approach has its disadvantages (for example, it is difficult to distinguish between the cases of descriptive translation and the translation by free word combinations), but it shows the "idiomatic character" of those terminological systems which are the most deeply integrated into literary language (Akar, 2016; Byker \& Marquardt, 2016; Korableva and Kalimullina, 2016; Husnutdinov et al., 2016 a).

The present article deals with the practical and theoretical aspects of the translation of the terms, in which the imagery does not find any reflection in the target language (Korableva and Kalimullina, 2014; Gabidullina, 2014; Gabidullina and Sattarova, 2015). The cases of the translation from English into Russian and from Russian into English are under study. In this article ideas expressed in the previous publications are being developed.

\section{Materials and methods}

Table 1 represents the most interesting examples of comparing English and Russian compound legal terms:

Table 1. The most interesting examples of comparing English and Russian compound legal terms

\begin{tabular}{|l|l|l|}
\hline $\begin{array}{c}\text { English word } \\
\text { combination }\end{array}$ & \multicolumn{1}{|c|}{$\begin{array}{c}\text { Russian translation and its word-for- } \\
\text { word meaning }\end{array}$} & \multicolumn{1}{|c|}{ Commentary } \\
\hline Civilly dead & $\begin{array}{l}\text { Lishennyy grazhdanskikh prav (deprived } \\
\text { of civil rights) }\end{array}$ & $\begin{array}{l}\text { In the Russian language the term is a } \\
\text { three-component word combination. } \\
\text { There is no reference to death in the to } \\
\text { semantic structure }\end{array}$ \\
\hline $\begin{array}{l}\text { To cross the } \\
\text { aisle }\end{array}$ & $\begin{array}{l}\text { Golosovat protiv svoey partii (to vote } \\
\text { against one's own party) }\end{array}$ & $\begin{array}{l}\text { Rendering imagery is impossible in } \\
\text { Russian as there is no tradition for the } \\
\text { representatives of the opposing parties to } \\
\text { sit facing each other }\end{array}$ \\
\hline To die seized & $\begin{array}{l}\text { Umeret, ostaviv imushestvo pod arestom } \\
\text { to die with the property having been } \\
\text { left under arrest) }\end{array}$ & $\begin{array}{l}\text { The English term is compact because the } \\
\text { norms of the ;anguage allow to use } \\
\text { lexeme "seized" in figurative meaning }\end{array}$ \\
\hline Slim evidence & $\begin{array}{l}\text { Nesusheestvuyushee } \\
\text { (non-existent evidence) }\end{array}$ & $\begin{array}{l}\text { The grammatical structure in two } \\
\text { languages is similar. The source of } \\
\text { semantic shift is the human world. }\end{array}$ \\
\hline $\begin{array}{l}\text { Father of the } \\
\text { Bar }\end{array}$ & $\begin{array}{l}\text { Starshyi barrister (senior barrister) } \\
\text { human relations }\end{array}$ \\
\hline
\end{tabular}




\begin{tabular}{|c|c|c|}
\hline To drop a right & $\begin{array}{l}\text { Otkazatsya ot prava (to refuse fron a } \\
\text { right) }\end{array}$ & $\begin{array}{l}\text { The source of imagery is the world of } \\
\text { physical states. In Russian the verb "to } \\
\text { drop" is not used in legal meaning. }\end{array}$ \\
\hline To find bail & $\begin{array}{l}\text { Ukazat poruchitelya (to indicate a } \\
\text { guarantor) }\end{array}$ & $\begin{array}{l}\text { The English variant nominates } \\
\text { the action directly while the Russian } \\
\text { language shows a tendency for a more } \\
\text { bookish variant. }\end{array}$ \\
\hline $\begin{array}{l}\text { Slap-on-the- } \\
\text { wrist fine }\end{array}$ & $\begin{array}{l}\text { Shtraf na meste soversheniay } \\
\text { pavonarshenya (fine at the scene of } \\
\text { breaking the law) }\end{array}$ & $\begin{array}{l}\text { Metonymy is the basis for the English } \\
\text { term, the Russian variant is represented } \\
\text { by the definition. }\end{array}$ \\
\hline $\begin{array}{l}\text { Fidelity } \\
\text { insurance }\end{array}$ & $\begin{array}{l}\text { Strahovaniye na sluchai narusheniya } \\
\text { obyazatelstva (insurance in case of } \\
\text { breaking the engagement) }\end{array}$ & $\begin{array}{l}\text { The source of the shift is the world of } \\
\text { human relations. The image does not } \\
\text { exist in the linguistic worldview of the } \\
\text { speakers of Russian }\end{array}$ \\
\hline $\begin{array}{l}\text { Employment } \\
\text { (job) freeze }\end{array}$ & $\begin{array}{l}\text { Vremennoye uvolneniye (leaving the job } \\
\text { for some time/the stop of the job } \\
\text { contract) }\end{array}$ & $\begin{array}{l}\text { The norms of the Russian language do } \\
\text { not allow the use of metonymy "freeze" in } \\
\text { this case. }\end{array}$ \\
\hline $\begin{array}{l}\text { Left-handed } \\
\text { oath }\end{array}$ & Lozhnaya prisyaga (false oath) & $\begin{array}{l}\text { There was no tradition to put the right } \\
\text { hand on the Bible in Soviet Russia }\end{array}$ \\
\hline Binding law & Imperativnaya norma (imperative norm) & $\begin{array}{l}\text { The word combination vividly shows a } \\
\text { much looser connection of judicial } \\
\text { terminology in Russian with the common } \\
\text { literary language }\end{array}$ \\
\hline To meet a claim & $\begin{array}{l}\text { Osparivat isk (to argue/debate a } \\
\text { claim)/podgotovit vozrazheniya protiv } \\
\text { iska (to prepare objections against a } \\
\text { claim) }\end{array}$ & $\begin{array}{l}\text { The English compound terms contains in } \\
\text { its semantic structure a reference to a } \\
\text { competitive nature of a trial procedure }\end{array}$ \\
\hline
\end{tabular}

The above-mentioned examples show that the largest group of the compound terms in this research is represented by word combinations translated into Russian by terminological collocations without a shift of meaning in their semantic structure (Molchanov et al., 2017). The shift of meaning influences the grammatical structure of compound terms. If there is no equivalent/analogous word combination the compound term is rendered by a phrase while the English variant is much more compact and occupies less space in a sentence (Magsumov, 2017; Magmusov, 2013; Husnutdinov et al., 2016 b; Akhmetshin et al., 2017; Korableva and Guseva, 2015).

Legal English has a certain number of compound terms for understanding of which background knowledge is not necessary. For example, one can easily grasp the meaning of such word combinations as slim evidence, star witness, standing rule without applying to a special dictionary. However, motivated those word combinations might seem to us the norms of the literary Russian make the use of loan translation utterly impossible.

Legal Terminology of the Russian language also has compound terms which contain a semantic shift, but their English translations have no imagery in their semantic structure 
(Çalışkan, 2015; Günel, \& Pehlivan, 2015; Kenna \& Russell, 2015; Korableva et al., 2017a; Aydarova et al., 2017).

The compound term zaverit kopiyu - to certify a copy the Russian verb the primary meaning of which is "to assure somebody of something by promising something or trying to persuade" is used metonymically. In English the meaning of the verb in the compound term is the main one (Ozhegov, 100; Longman, 181). Let us look at the compound term "provodit zakony $\mathrm{v}$ zhizn - to applylenforce (to execute laws"). The primary meaning of the Russian verb is "lead" and in this word combination it has the meaning of "to achieve something". In the English language the semantic transfer on the same basis is impossible as the verb "to lead" has a different meaning and combinability (one can lead a life, but one can not lead into life).

The word combination snimat s sebya otvetstveenost - to deny one's liability/responsibility is also interesting for consideration. First of all, the Russian language does not have a special lexeme for "liability" denoting legal responsibility. The word for word meaning of the verb in the Russian compound term is "to take off" so it sounds as if you "took off your responsibility (Ozhegov, 7). In the word combination tyazhest obvineniya ("seriousness of an accusation") the accusation is described as heavy ("heaviness of an accusation") which is more expressive than serious. So here the expressive component in the semantic structure of the Russian word combination can be identified.

\section{Discussion}

The classification of set expressions into nominative and expressive has been used in research on Phraseology (Kunin 1996). We believe that one can speak about expressive functions of compound terms, at least in those terminological systems which are the closest to the common literary language (Shkilev 2013). The function of imaginative rethinking in the semantic structure of compound terms is to express additional connotations.

The problem to be discussed here is whether such language units should be treated only as part of the field of Terminology or they should be studied by Phraseology as well (Korableva et al., 2017b; Akhmetshin and Osadchy, 2015; Tarman \& Chigisheva, 2017). It seems that if a compound term containing imagery in its semantic structure is able not only to nominate an object or phenomenon but to communicate expressive meaning it is of interest to both terminologists and phraseologists and should be studied by both branches of linguistics.

\section{Conclusion}

The bulk of judicial terminology of the English language has been formed many centuries ago which may be explained by the stability of the political system in Britain. Stability being the reason for the lack of serious changes accounts for a great number of compound terms with a transfer in the semantic structure. Our investigation has revealed that the transfer of images from the world of nature as well as from the human world is not typical of the legal terminology of the Russian language. 


\section{Acknowledgement}

The work is performed according to the Russian Government Program of Competitive Growth of Kazan Federal University.

\section{References}

Akhmetshin, E. M., Makulov, S. I., Talysheva, I. A., Fedorova, S. Y., \& Gubarkov, S. (2017). Overcoming of intercultural barriers in the educational environment. Man in India, 97(15), 281-288.

Akhmetshin, E. M., \& Osadchy, E. A. (2015). New requirements to the control of the maintenance of accounting records of the company in the conditions of the economic insecurity. International Business Management, 9(5), 895-902. doi:10.3923/ibm.2015.895.902

Arsentyeva, Elena. (1999). Russian-English phraseological dictionary. Kazan: Haeter Publishing House.

Akar, C. (2016). Investigating the students' perceptions of the democratic values of academicians. Journal of Social Studies Education Research, 7(1), 96-139. doi:10.17499/jsser.496o1

Aydarova S. H., Giniyatullina L. M., Sagdieva R. K., Husnutdinov D. H., Mirzagitov R.H., Gabidullina F.I. (2017). Models of media education in teaching Tatar language. Espacios, Vol. 38 (6o).

Byker, E. J., \& Marquardt, S. K. (2016). Using critical cosmopolitanism to globally situate: Multicultural education in teacher preparation courses. Journal of Social Studies Education Research, 7(2), 30-50.

Çalışkan, H. (2015). An investigation into the organization levels of social studies teachers with regard to constructivist learning environments in terms of several variables. [Sosyal bilgiler öğretmenlerinin Yapılandırmacı öğrenme ortamlarını düzenleme düzeylerinin çe?itli değişkenlere göre İncelenmesi] Journal of Social Studies Education Research, 6(1), 49-83. doi:10.17499/jsser.0o913

Gabidullina F.I. (2014). Religious motives in the work of Sagit Sunchalay and Anna Akhmatova. Recent Trends in Social and Behaviour Sciences - Proceedings of the 2nd International Congress on Interdisciplinary Behavior and Social Sciences 2013, ICIBSoS 2013. pp: 475 - 477.

Gabidullina, F.I., Sattarova, G.G. (2015) Reflects the traditions in contemporary prose. Mediterranean Journal of Social Sciences. Vol 6, No 5, pp.: 201 - 203. DOI: 10.5901/mjss.2015.v6n5s2p201

Günel, E., \& Pehlivan, A. (2015). Examining the citizenship and democracy education textbook and curriculum in terms of global education. [Küresel eğitim çerçevesinde vatandaşlık ve demokrasi eğitimi ders kitabı ve öğretim programı] Journal of Social Studies Education Research, 6(1), 123-171. doi:10.17499/jsser.88468s

Husnutdinov, D.H., Sagdieva, R.K., Mirzagitov, R.H. (2016a). Comparative constructions in G. Ibragimov's works. Journal of Language and Literature. 2016. Vol. 7. No. 4. P. 42-45.

Husnutdinov, D.H., Yusupova, Z.F., Shakurova, M.M., Yusupov, A.F., Mirzagitov, R.H. (2016b). Practical aspect of comparative research on the material of the Russian and Tatar languages: XIX-XXI centuries. Journal of Language and Literature. Vol.7, Is.2. - P.191-194.

Kenna, J. L., \& Russell, W. B. (2015). Secondary social studies teachers' time commitment when addressing the common core state standards. Journal of Social Studies Education Research, 6(1), 26-48. doi:10.17499/jsser.37219

Korableva, O., Guseva, M. (2015). Activation of innovation processes in banks as a result of the implementation of basic basel accord provisions. Ikonomicheski Izsledvania, 24(3), c. 108-128

Korableva O., Kalimullina O. (2014). The Formation of a single legal space as a prerequisite for overcoming systemic risk. Asian Social Science, Vol. 10 (21), 256-260. 
Korableva O., Kalimullina O. (2016). Strategic Approach to the Optimization of Organization Based on the BSC SWOT Matrix. Proceedings of the International Conference on Knowledge Engineering and Applications. ICKEA, 2016. Singapore, September 28-30, 2016. p. 212-215

Korableva O. N., Kalimullina O. V., Kurbanova E.S. (2017a). Building the monitoring systems for complex distributed systems: Problems \& solutions. ICEIS 2017 - Proceedings of the 19th International Conference on Enterprise Information Systems, Portugal, Porto, 26-29 April 2017, pp 221-228.

Korableva O. N., Razumova I. A., Kalimullina O. V. (2017b). Research of Innovation Cycles and the Peculiarities Associated with the Innovations Life Cycle Stages. Proceedings of 29th IBIMA Conference, Vienna, Austria, 3 - 4 May 2017, pp 1853-1862.

Kunin, Alexander. (1996). A course of English Phraseology. Moscow: Fenix Publishing House.

Longman Dictionary of Contemporary English. 1995. Essex Longman House.

Magsumov, T.A. (2017). Family and school in Russia at the beginning of the 2oth century: Attempts to bridge the gap. European Journal of Contemporary Education. 6 (4): 837-846. DOI: 10.13187/ejced.2017.4.837

Magmusov, T.A. (2013). School and children during the celebrations of the 3ooth anniversary of the romanov dynasty. Bylye Gody. (4) 30: 79-87.

Molchanov, N.N., Korableva, O.N., Muraveve, O., Galay, N. (2017). Neuromarketing as an innovative approach to market research of consumer behavior. Proceedings of 29th IBIMA Conference, Vienna, Austria, 3 - 4 May 2017, pp. 2489-2499

Ozhegov, Sergey. (2004). Explanatory dictionary of the modern Russian language. Moscow: TEMP Publishing House.

Shkilev, Roman. (2010). Imaginative rethinking in compound terms. Naberezhnye Chelny: The printing office of Kazan Federal University.

Shkilev, Roman. (2013). "Nominative-expressive and expressive-nominative stable word combinations in English and Russian legal terminology". Middle East Journal of Scientific Research 17 (4): 419-423.

Steingart, E. (2006). "Motivational terminology". The Bulletin of Krasnoyarsk State Pedagogical University 3: 30-34.

Tarman, B., \& Chigisheva, O. (2017). Transformation of educational policy, theory and practice in postsoviet social studies education. Journal of Social Studies Education Research, 8(2), I-IV. doi:10.17499/jsser.93128 